\title{
The Impact of Great Recession on Developing Countries: The Case of India and Argentina
}

\author{
Hilal Tezcan \\ PhD Candidate \\ Head of Department at Presidency of Strategy and Budget \\ Çankaya/ Ankara/Turkey
}

\begin{abstract}
The great recession starting in the US sub-prime mortgage market in 2008 was considered to be the deepest crisis since the great depression of 1929. At the very beginning of the crisis, it was considered as a local crisis but it had spread to worldwide through highly integrated financial system including both developed and developing economies. Even if the developing economies did not suffer as much as the developed ones, they were influenced through the international trade and capital flows. India and Argentina were two of those developing countries that suffered from the global crisis, even if they are located in different hemispheres and had different conditions. Therefore, examining the impact of the global crisis on these countries and their policy responses to this crisis would help to have an insight into the worldwide financial crisis.
\end{abstract}

Keywords: The great recession, integrated global financial system, developing countries, international trade, capital flows

\section{Introduction}

After the abolishment of the Glass-Steagall Act of 1933 that was enacted to restrict commercial banks' involvement in investment banking, financial markets had been deregulated in the United States (US). In a highly deregulated atmosphere, innovative financial instruments, huge financial institutions and a shadow banking system had become widespread. On the other hand, in the aftermath of the internet bubble in 2000 and 9/11 terrorist attacks, US and other developed countries adopted expansionary monetary policies and the credit expansion had created another bubble. Financial system in advanced economies mostly followed the same path with the US and invested in same kind of innovative financial instruments. Investors invested in those instruments without knowing the inherent risk since they relied on financial giants and credit rating institutions. When the Lehman Brothers collapsed, it was believed that its collapse led to the global crisis, but it was the underlying issues made Lehman Brothers collapsed.

The crisis that started in the US mortgage market had spread to the countries around the world through highly integrated global financial system and influenced all economies including both advanced and developing ones. Developing countries had not been affected as much as the advanced ones since they had experienced many crises previously and faced the global crisis more prepared. However, at the very beginning of the crisis it was thought that developing countries would not been affected and would continue to contribute the world economic growth. But it was seen that developing economies were also influenced through the international trade and capital flows. Their exports and capital inflows were mostly dependent on the advanced economies, and when the advanced economies got into recession their export incomes and capital inflows declined.

India and Argentina were two of these economies that were influenced by the global crisis, even if they were located in different regions and had different conditions. They both experienced a decrease in international trade and capital inflows that led them to an economic downturn. On the other hand, even if its growth rate dropped sharply, India had not experienced a negative growth while the Argentina's GDP growth was $-5.9 \%$ in 2009. They both had a V-shape recovery during the global crisis but Argentina's growth rates started to decrease again following the year 2011 while India showed a better performance. Therefore, it is important to examine these two countries, to understand the channels that spread the crisis to the developing countries, even if they are located in very far away from each other. In this study it is aimed to reveal the underlying issues of the global crisis and to point out the economic fragilities and policy responses of these two developing countries during the global crisis.

\section{The Great Recession and Developing Countries}

As of 1980s, US mortgage markets were liberalized through raised borrowing limits and reduced asset requirements for loans by neoliberal governments starting with Reagan administration that led increased financial leverage. Beginning in 1987, the Glass-Steagall Act was weakened step by step and fully repealed in 1999 which was enacted in 1933 to restrict commercial banks' involvement in investment banking after the Great Depression of 1929. 
This kind of neoliberal deregulations resulted in huge financial institutions that involved in many kinds of financial services through innovated financial instruments. (Steger \& Roy, 2010).In addition to this, the bubble created through internet based companies in 2000 and 9/11 terrorist attacks caused expansionary policies in the US and other developed countries. Low interest rate policy of Federal Reserve and increasing house prices resulted in credit growth and contributed to another bubble (Lin, 2008).

Aforementioned new financial instruments innovated by financial sector had become popular since those instruments enormously supported economic growth, and a shadow banking system emerged consisting of new kind of financial institutions which provided credits to huge number of borrowers including corporations as well as individuals(Roubini \& Mihm, 2010). Investment banks bought high risky adjustable rate subprime mortgage loans and resold them by creating complex securities such as "collateralized debt obligations". Investors bought those instruments without knowing the inherent risk since they relied on financials giants and credit rating institutions, and an expansive bubble was created (Steger \& Roy, 2010). At the end, it was understood that the boom triggered by the financial sector transformed into a bubble. Upon the burst of the bubble, a financial crisis arose, some of the huge financial institutions such as Lehman Brothers collapsed and the impact of the crisis had spread around the world through the integrated financial system (Naudé, 2009). This financial crisis arose from the subprime mortgage market in US in late 2008 affected the whole world's economy and led to a great recession unprecedented since the Great Depression of 1929(Roubini \& Mihm, 2010). Highly integrated financial markets facilitated the contagiousness of the crisis that led to decline in credits, consumption, investment and trade, and the most of the countries around the world were affected by it, including both developed and developing ones(Naudé, 2009).

Priewe stresses that aforementioned causes of crisis can be explained within the context of market and government failures. In that vein, there were market failures such as asymmetric information and monopoly. The first one arose from the ignorance of investors about the inherent risks of innovative financial instruments. The second market failure was because of the huge financial institutions deemed "too big to fail". Also there were government failures such as expansionary monetary policy, highly deregulated financial markets and the Congress's vulnerability to the pressure of Wall Street lobby for deregulated financial markets. On the other hand, those factors do not comprise the whole story since they focus on the supply side and neglect the demand side as in the case of enormous demand for risky assets. Therefore, even if the market and government failures contributed to this crisis, the capital account deficits of debtor countries such as the US and the high saving rates of lenders such as China had created global imbalances (Priewe, 2010).

Because of the downturn in economies; funding markets had been narrowed, equity markets could not make sufficient gains, and currency markets had been volatile. Central banks took action against crisis and decreased interest rates strongly to improve credit provision, especially in advanced economies. In addition to expansionary monetary policies, governments in both developed and developing countries announced expansionary fiscal packages to foster economic activity and mitigate adverse effects of the global crisis(IMF, 2009). Despite the actions taken by governments, the crisis had rapidly spread to the real sectors that paved the way for the great recession through a sharp decline in output and employment (Nayyar, 2011). For instance, unemployment rate rose sharply in the OECD area and reached 8.7\%. Among young people, the situation got worse and the young unemployment rate rose more than 8 percentage points. Therefore, the route of the crisis can be summarized as fall in housing prices, liquidity and insolvency problems of the banks, loss of consumer confidence, slowdown in businesses, collapse of trade and increased unemployment. (Keeley \& Love, 2010).

On the other hand, even if the great recession is claimed to be the deepest crisis since 1929, the important difference between these two is developing countries have been much more integrated to the global economy since the great depression. For this reason, it is of utmost importance that developing economies should be examined delicately to understand the total impact of the great recession on the global economy(Nayyar , 2011).

\subsection{The Impacts of Great Recession on Developing Countries}

Between 2002 and 2007, developing economies enjoyed the boom in advanced economies through the increased commodity prices and export revenues, foreign direct investment inflows and the increase in received remittances. Because of this economic atmosphere in the global area, investment boomed in developing economies that caused the increase in capital demand from developed countries and this developments triggered their growth rates(Lin, 2008).

However, as is mentioned above, the crisis of 2008 had enormous negative impacts on developing countries as well as developed ones. Since advanced economies experienced a downturn during the global crisis, favorable economic situation had changed for the developing economies as well. There were several channels that led the global crisis to spread through the developing world. 
Those channels can be mainly listed as current account balance affected by export incomes and remittances and financial account balance affected by direct and portfolio investment flows (Nayyar , 2011).

Table 1: Main Economic Indicators by Country Groups

\begin{tabular}{|c|c|c|c|c|c|c|c|c|c|c|c|c|c|c|}
\hline \multirow[t]{2}{*}{ Country Groups } & \multicolumn{2}{|c|}{$\begin{array}{c}\text { GDP }^{1} \\
(\%)\end{array}$} & \multicolumn{2}{|c|}{$\begin{array}{c}\mathrm{CAB}^{2} \\
(\% \text { of } \mathrm{GDP})\end{array}$} & \multicolumn{2}{|c|}{$\begin{array}{c}\mathbf{F A B}^{3} \\
(\% \text { of } \mathbf{G D P})\end{array}$} & \multicolumn{2}{|c|}{$\begin{array}{l}\text { Revenue }^{4} \\
\text { (\% of GDP) }\end{array}$} & \multicolumn{2}{|c|}{$\begin{array}{c}\text { Total } \\
\text { Expenditure } \\
\text { (\% of GDP) }\end{array}$} & \multicolumn{2}{|c|}{$\begin{array}{c}\text { Net } \\
\text { Lending/Borrowing }^{4} \\
\text { (\% of GDP) }\end{array}$} & \multicolumn{2}{|c|}{$\begin{array}{l}\text { Gross Debt }^{4} \\
\text { (\% of GDP) }\end{array}$} \\
\hline & $(a)^{5}$ & $\left(\right.$ b) ${ }^{5}$ & (a) & (b) & (a) & (b) & (a) & (b) & (a) & (b) & (a) & (b) & (a) & (b) \\
\hline Advanced Economies & $2,3 \%$ & $1,4 \%$ & $-0,9 \%$ & $0,3 \%$ & $-1,1 \%$ & $0,3 \%$ & $35,4 \%$ & $35,7 \%$ & $38,1 \%$ & $40,3 \%$ & $-2,7 \%$ & $-4,6 \%$ & $74,0 \%$ & $101,7 \%$ \\
\hline $\begin{array}{l}\text { Emerging Market And } \\
\text { Developing Economies }\end{array}$ & $7,0 \%$ & $5,0 \%$ & $3,1 \%$ & $0,6 \%$ & $2,7 \%$ & $-0,1 \%$ & $26,0 \%$ & $27,3 \%$ & $26,6 \%$ & $30,1 \%$ & $-0,6 \%$ & $-2,9 \%$ & $42,7 \%$ & $41,0 \%$ \\
\hline
\end{tabular}

\section{Notes:}

1) Constant prices 2) Current account balance 3) Financial account balance 4) General government

5) (a): Average of the years 2002-2008, (b): Average of the years 2009-2017

Source: Derived from IMF's World Economic Outlook Data(IMF, World Economic Outlook Data, 2019).

Table 1 demonstrates several indicators related to macroeconomics and public finances in advanced economies (AE) as well as emerging markets and developing economies (EMDE) for the periods 2002-2008 and 2009-2017. When the indicators examined, it is obvious that the average growth rates had decreased from first period to the second in both country groups. In terms of the average $\mathrm{CAB}$, while the EMDEs experienced a decrease in current account surplus, AEsmet the deficit during the second period. Considering the dependence of developing countries on export income, the sharp decline in global trade hit those countries harshly. Not only small countries were mainly dependent on export but also large economies such as China and India were affected by the slowdown(Nayyar , 2011).

Figure 1: Volume of Imports and Exports of Goods and Services (\%)

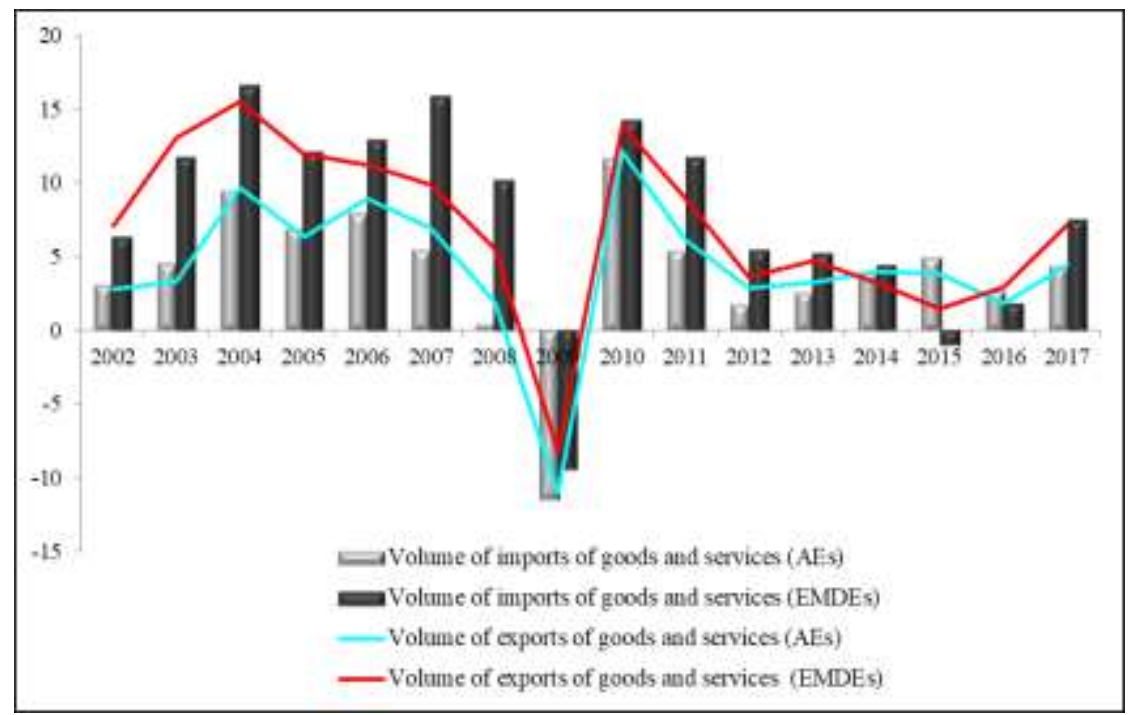

Source: Derived from IMF's World Economic Outlook Data(IMF, World Economic Outlook Data, 2019).

Figure 1 also demonstrates the volume of imports and exports for both AEs and EMDEs. As is seen from the figure, volume of imports and exports of goods and services fell in 2009 because of the impact of the great recession on both country groups. However, the decrease in EMDEs was sharper than the decrease in AEs compared with the pre-crisis level. For this reason, it can be said that the collapse of international trade was more disastrous for EMDEs than AEs, since declined credit availability for international trade stemming from advanced economies, had hit the exporters and importers in developing economies(Reddy, 2010).

In addition to $\mathrm{CAB}$, the developments related to $\mathrm{FAB}$ were also against the EMDEs after the great recession and the FAB as a share of GDP had decreased in EMDEs and those countries had experienced deficit in the second period. The capital outflows had also a negative impact on developing countries' currencies even for the countries that had large foreign-exchange reserves(The World Bank, 2010). In terms of the AEs, the data shows that there was an improvement in FAB as a share of GDP that increased from $-1.1 \%$ to $0.3 \%$. 
Therefore, the volatility of capital flows affects the EMDEs harsher than AEs since the EMDEs' economies are nascent. Also, it is not easy to access the international currency reserves for EMDEs since G-7 economies do not focus on those economies as much as the AEs and the financial markets behave differently to those economies in terms of risk-reward. On the other hand, there are other factors such as regulatory quality, policies and economic fundamentals that should be taken in consideration to evaluate the impact of the crisis on those countries(Reddy, 2010).

As a result of developments in the global area, public finances had also been affected tremendously both in the AEs and EMDEs. Even if the general government revenues as a share of GDP had increased, general government deficit as a share of GDP also increased in both country groups because of the increase in general government total expenditure as a share of GDP. Therefore, it can be interpreted as the governments in both country groups responded decreasing demand created by the great recession through increased government expenditures. However, as is seen from Figure 2, while the increase in general government deficit in AEs in 2009 was sharper than that in EMDEs, beginning from 2015, AEs experienced an improvement in general government deficit, contrary to EMDEs.

Figure 2: General Government Deficit (\% of GDP)

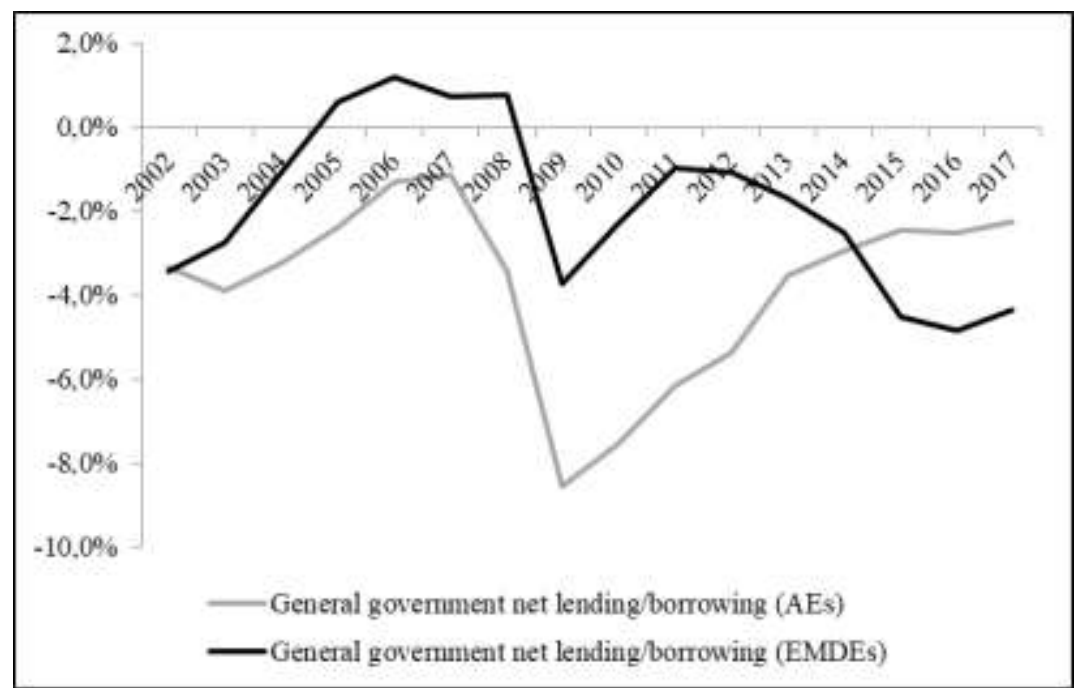

Source: Derived from IMF's World Economic Outlook Data(IMF, World Economic Outlook Data, 2019).

On the other hand, in terms of general government gross debt as a share of GDP, it is obvious that there was an enormous change in AEs which is increased from $74 \%$ to $101.7 \%$.Indeed, for the AEs, data shows that the general government gross debt as a share of GDP has never been less than $100 \%$ since 2011 . On the contrary, there was a slight improvement in EMDEsin comparison with the AEs.

As is mentioned previously, China was one of the developing economies that suffered severely during the recession. Exports decreased by 53\% compared with the pre-crisis level. However, Chinese government responded to the slowdown by means of expansionary fiscal and monetary policies to boost the economy. Yet, China was not the only country that implemented those policies; other countries including Brazil and India also followed a similar path(Keeley \& Love, 2010).However, even if there are similarities between the countries in terms of the impacts of the crisis and their policy responses, developing countries should be evaluated within their own context since they are different in terms of their development levels, financial sectors, level of integration to the world economy, becoming a commodity exporter or importer and the volatility of the local currencies(Reddy, 2010).

\section{The Great Recession and India}

India is defined as a union of states according to the India's Constitution of 1949 and consists of twenty nine states and seven union territories. President of India represents the executive power and the legislative power used by the parliament and the legislatures of the states(Government of India, 2015). It is the second most populated country following China and in 2017 it was the fifth largest economy in the world after United States, China, Japan and Germany with 2,652 billion US dollars of GDP(IMF, 2019). Therefore, as one of the largest economies in the world with an increasing integration, India has an enormous importance in the global economy and it was affected by the great recession as in the case of other emerging markets and developing economies.

\subsection{Pre-crisis Period in India}

India experienced a financial and balance of payment crisis at the beginning of 1990s that led the country to implement an economic reform program including liberalization of capital markets and trade regime and structural measures. 
The reform program comprised industrial, trade and financial sectors, and it was very comprehensive compared with the previous programs. As a result, India had high level of growth rates after the mid-1990s(Bajpai, 2002).

Table 2: Main Economic Indicators of India (1990-2005)

\begin{tabular}{lrrrr}
\hline & $\mathbf{1 9 9 0}$ & $\mathbf{1 9 9 5}$ & $\mathbf{2 0 0 0}$ & $\mathbf{2 0 0 5}$ \\
\hline \hline Gross domestic product, constant prices (\%) & 5,5 & 7,6 & 4,0 & 9,3 \\
Inflation, average consumer prices (\%) & 11,2 & 10,0 & 3,8 & 4,4 \\
Volume of imports of goods and services (\%) & 5,6 & 17,5 & 2,2 & 16,7 \\
Volume of exports of goods and services (\%) & 4,0 & 13,3 & 11,4 & 17,9 \\
Current account balance (\% of GDP) & $-2,9$ & $-1,6$ & $-0,6$ & $-1,2$ \\
General government revenue (\% of GDP) & 17,4 & 17,9 & 17,4 & 19,1 \\
General government total expenditure (\% of GDP) & 25,4 & 24,5 & 25,6 & 26,4 \\
General government net lending/borrowing (\% of GDP) & $-7,9$ & $-6,7$ & $-8,3$ & $-7,4$ \\
General government gross debt (\% of GDP) & $\mathrm{n} / \mathrm{a}$ & 69,7 & 73,6 & 80,9 \\
\hline
\end{tabular}

Source: Derived from IMF's World Economic Outlook Data(IMF, World Economic Outlook Data, 2019).

Table 2 demonstrates the developments in some economic indicators of India. As is seen, even if there was a decline in 2000, India had increased its growth rates between the years 1995-2005.Also, inflation rates had decreased, the percentage change in volume of export and import of goods and services increased except for in 2000, and the current account balance had been improved in comparison with the year 1990. However, in terms of public finance, India was not able to make impressive improvements since the general government deficit as a share of GDP maintained high and the general government gross debt as a share of GDP had increased from 69.7\% in 1995 to $80.9 \%$ in 2005 .

\subsection{The Impact of the Great Recession on Indian Economy}

At the beginning of the global financial crisis, it was believed that India would not be affected by the crisis severely because of its strong fundamentals and well-regulated banking system(Khan, 2011). However, the value of exports had been declined from October 2008 to April 2009 compared to the previous year's values for the same months. The trend was similar for imports, and in December 2008 a negative import growth was experienced(Jansen \& Von Uexkull, 2010).

Therefore, as is seen from the Table 3, global crisis arrived India in 2008 and economic indicators of the country had been deteriorated in parallel with the global developments. India experienced a 3.9\% GDP growth in 2008, after 8.8\% average growth in previous five years. In the following years, GDP growth rate had increased again but the average growth between 2009 and 2017 was 7.6\% and never reached its pre-crisis values except for in 2010.Inflation also rose from $6.2 \%$ in 2007 to $9.1 \%$ in 2008 . It had remained high between 2009 and 2013 with a $10.3 \%$ average, but started to decrease in 2014 and reached the lowest value in 2017 since 1990.

Table 3: Main Economic Indicators of India (2006-2017)

\begin{tabular}{|c|c|c|c|c|c|c|c|c|c|c|c|c|}
\hline & 2006 & 2007 & 2008 & 2009 & 2010 & 2011 & 2012 & 2013 & 2014 & 2015 & 2016 & 2017 \\
\hline $\begin{array}{l}\text { Gross domestic product, } \\
\text { constant prices (\%) }\end{array}$ & 9,3 & 9,8 & 3,9 & 8,5 & 10,3 & 6,6 & 5,5 & 6,4 & 7,4 & 8,0 & 8,2 & 7,2 \\
\hline $\begin{array}{l}\text { Inflation, average consumer } \\
\text { prices }(\%)\end{array}$ & 6,7 & 6,2 & 9,1 & 12,3 & 10,5 & 9,5 & 10,0 & 9,4 & 5,8 & 4,9 & 4,5 & 3,6 \\
\hline $\begin{array}{l}\text { Volume of imports of } \\
\text { goods and services (\%) }\end{array}$ & 11,5 & 18,8 & 3,0 & 4,6 & 15,8 & 10,6 & 1,8 & $-3,4$ & 5,4 & $-0,2$ & 4,0 & 13,8 \\
\hline $\begin{array}{l}\text { Volume of exports of } \\
\text { goods and services }(\%)\end{array}$ & 16,0 & 18,5 & 7,0 & $-4,5$ & 26,5 & 12,1 & 0,7 & 5,3 & 3,9 & $-5,5$ & 6,7 & 10,0 \\
\hline $\begin{array}{l}\text { Current account balance } \\
\text { (\% of GDP) }\end{array}$ & $-1,0$ & $-1,3$ & $-2,3$ & $-2,8$ & $-2,8$ & $-4,3$ & $-4,8$ & $-1,7$ & $-1,3$ & $-1,1$ & $-0,6$ & $-1,8$ \\
\hline $\begin{array}{l}\text { General government } \\
\text { revenue ( } \% \text { of GDP) }\end{array}$ & 20,3 & 22,0 & 19,7 & 18,5 & 18,8 & 19,3 & 19,8 & 19,6 & 19,1 & 19,9 & 20,2 & 19,8 \\
\hline $\begin{array}{l}\text { General government total } \\
\text { expenditure ( } \% \text { of GDP) }\end{array}$ & 26,7 & 26,5 & 28,7 & 28,1 & 27,4 & 27,6 & 27,4 & 26,6 & 26,2 & 27,1 & 27,3 & 26,8 \\
\hline $\begin{array}{l}\text { General government net } \\
\text { lending/borrowing ( } \% \text { of } \\
\text { GDP) }\end{array}$ & $-6,3$ & $-4,5$ & $-9,0$ & $-9,5$ & $-8,6$ & $-8,3$ & $-7,6$ & $-7,0$ & $-7,1$ & $-7,2$ & $-7,1$ & $-7,0$ \\
\hline $\begin{array}{l}\text { General government gross } \\
\text { debt }(\% \text { of GDP) }\end{array}$ & 77,1 & 74,0 & 74,5 & 72,5 & 67,5 & 69,6 & 69,1 & 68,5 & 67,8 & 69,9 & 69,0 & 69,8 \\
\hline
\end{tabular}

Source: Derived from IMF's World Economic Outlook Data(IMF, World Economic Outlook Data, 2019). 
To understand the impact of the global crisis on growth rates deeply, it is important to examine sectoral developments. The average annual growth rates of four main sectors can be seen from the Figure 3. As is seen, the average annual growth for each sector decreased between 2003 and 2007 except agriculture sector in comparison with the first period. In 2008, there was a tremendous decrease in each sector's growth except services. However, the average growth in industry and services increased while it decreased in agriculture and manufacturing. It can be seen from Figure 3 that the agriculture sector was the most affected one during the global crisis. On the other hand, even if all sectors showed a better performance in the fourth period, the sectoral growth rates had been volatile in this period.

Figure 3: Average Annual Growth in Main Sectors - India (Value Added, Annual \%)

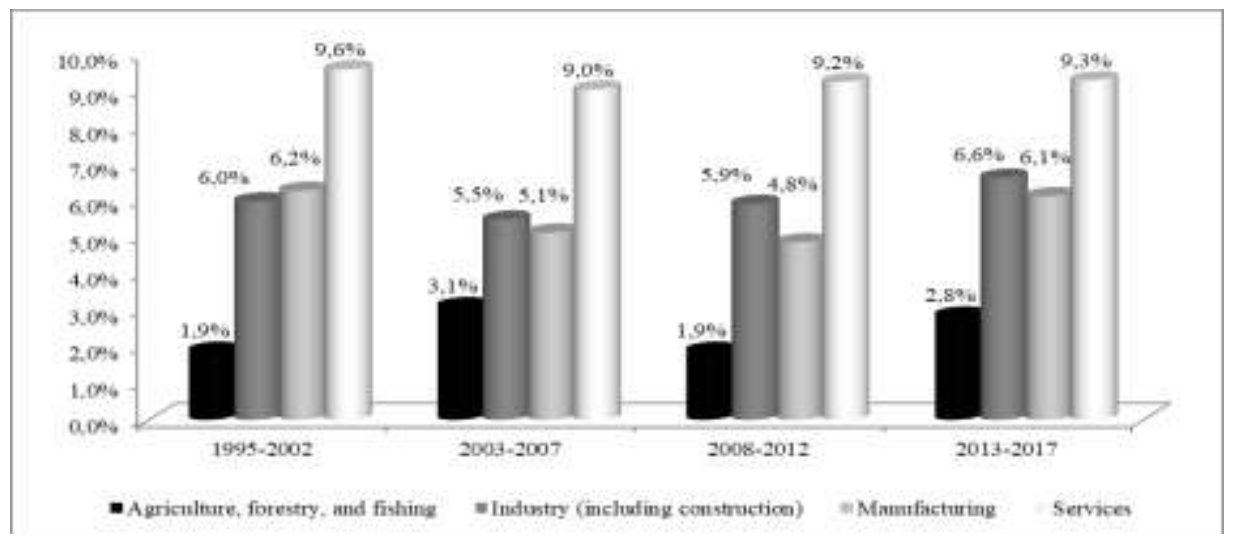

Source: Derived from the World Bank's World Development Indicators Data(The World Bank, 2019).

Indeed, it was the international trade indicators influenced worse than any other. In 2008, the growth in volume of imports of goods and services decreased to $3 \%$ from $18.8 \%$, and the growth in volume of exports of goods and services decreased to $7 \%$ from $18.5 \%$. In 2009, even if there was a slight recovery in terms of the import growth, the export growth rate was worse than it was in 2008. As a result, current account deficit as a share of GDP got worsen and increased from $-1.3 \%$ in 2007 to $-2.3 \%$ in 2008 and to $-2.8 \%$ in 2009. In the aftermath of the crisis, the growth in import and export had never reached its pre-crisis period. The average import growth rate decreased to $5.9 \%$ between 2009 and 2013 while it was $18.3 \%$ between 2003 and 2007. The drop in average export growth rate was also sharp since it decreased to $8 \%$ between 2009-2013 while it was $19.1 \%$ between 2003 and 2007. Between the years 2014 and 2017, the average growth in both import and export was worse than the previous five years' average, as well.

When the public finance indicators of India are examined, it is seen that general government revenues as a share of GDP decreased and general government expenditures as a share of GDP increased in 2008 compared to the previous years. It can be interpreted as India implemented an expansionary fiscal policy as a respond to the global crisis. Therefore, general government deficit and gross debt as a share of GDP increased as a consequence of this expansionary fiscal policy. Additionally, Figure 4 shows that when the GDP growth increases, the general government deficit decreases in India and vice versa. Therefore, it can be said that India prefers to compensate the decrease in GDP growth at the expense of fiscal deficit.

Figure 4: GDP Growth and General Government Deficit (India)

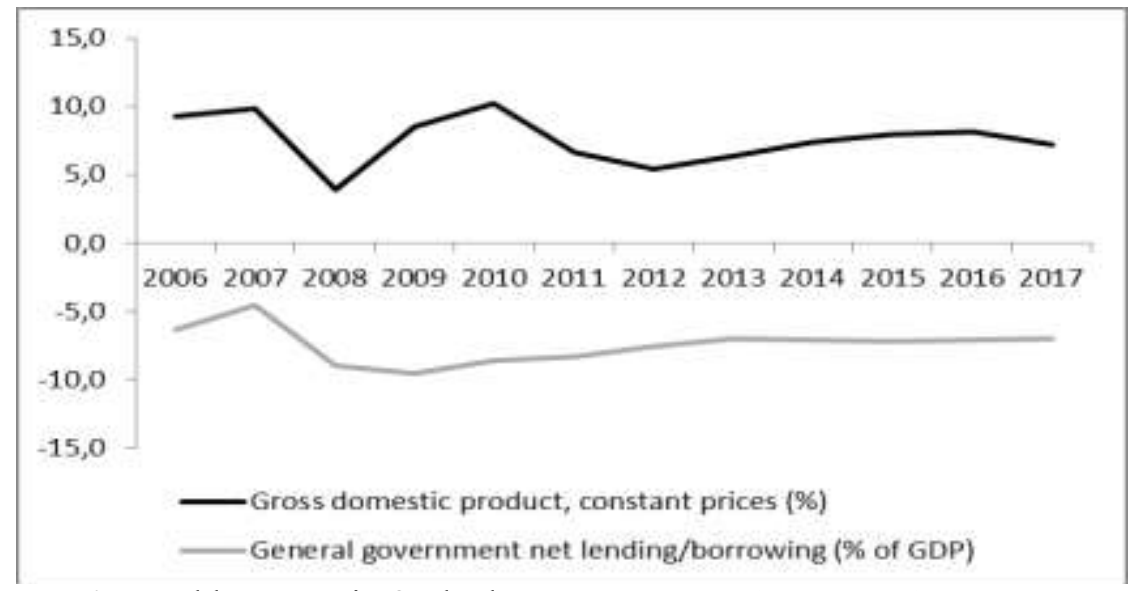

Source: Derived from IMF's World Economic Outlook Data (IMF, World Economic Outlook Data, 2019) 
On the other hand, as is seen from Table 4, the foreign investments in the balance of payments of India also show that country had been influenced negatively in terms of portfolio investments, beginning from 2008. From April 2008 to March 2009 net portfolio investments of India decreased from 27.4 billion US \$ to -14 billion US \$.

Table 4: Foreign Investments of India (2005-2009)

April - March (US \$ million) $\quad 2005-06 \quad 2006-07 \quad 2007-08 \quad 2008-09$

$\begin{array}{lllll}\text { Foreign Direct Investment } & 3.034 & 7.693 & 15.893 & 19.816 \\ & & & & \\ \text { Portfolio Investment } & 12.494 & 7.060 & 27.433 & -14.031\end{array}$

Source: Derived from Reserve Bank of India's Archives (Reserve Bank of India, 2011)

In addition to this, Figure 5 shows the foreign investments as a share of GDP for the years 1995-2017. As is mentioned before, the global crisis spread to India in 2008 and Figure 5demonstrates that in the aftermath of the global crisis, India was hit through foreign investments including both direct and portfolio investments. At the very beginning of the crisis, foreign institutional investment flows increased since it was believed that the emerging economies would not be affected by the crisis and they would continue to contribute to the world's economic growth. However, the global crisis deepened and spread to those economies through balance of payments and net portfolio inflows of India was negatively affected since foreign institutional investors sold equity stakes because of liquidity requirements (Bajpai, 2011). Also, Figure 5 shows that even in the following years, foreign investments were more volatile in comparison with the precrisis period.

Figure 5: Foreign Investments of India (\% of GDP)

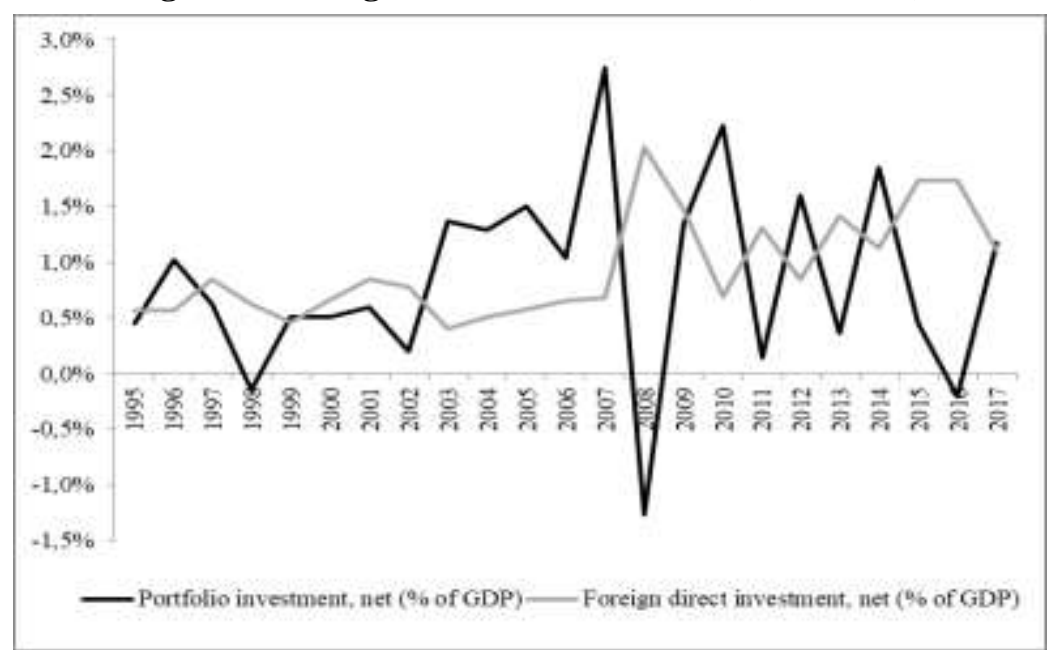

Source: Derived from the World Bank’s World Development Indicators Data(The World Bank, 2019)

\subsection{Policy Responses of India to the Great Recession}

Even if India has adopted liberal market policies since 1990s, fiscal policy has been an important tool to fight poverty and environmental issues. As a result, tax, expenditure and public debt have been used as effective means to ensure equality in allocation of resources. Therefore, when the global crisis arrived the country, India took some measures such as tax cuts and additional expenditures. Two of the main expenditure items were the social security obligations such as National Rural Employment Guarantee Act (2005) and the payment of pay revision arrears to the government employees(Khan, 2011). Indeed, the tax reliefs focused on boosting the demand and additional public expenditures mainly focused on creating employment and assets(Bajpai, 2011). Also, the governments were allowed to be more flexible in terms of the fiscal policy despite they were obliged to ensure fiscal consolidation in pre-crisis period. Even if there was a small decline, those expansionary policies helped the country to continue to grow, which was an important success compared to the other countries experiencing sharp negative growth rates(Khan, 2011).

In terms of monetary policy, as its counterparts did, Reserve Bank of India eased money supply and increased liquidity through reduced repo rate, reverse repo rate and cash reserve ratio and enhanced provision of primary liquidity. Liquidity injection was made through the banks and the balance sheet of the Reserve Bank of India did not increase since the released liquidity was sterilized in the pre-crisis period(Mohanty, 2009). 
The Reserve Bank of India's main target was to mitigate the contradiction in liquidity arisen from foreign financial markets and to improve the foreign exchange liquidity. Also, some specific credit measures were taken aiming at specific sectors such as exportation, housing, micro and small enterprises and infrastructure(Bajpai, 2011).

\section{The Great Recession and Argentina}

According to the Constitution of 1853, Argentina is defined as a federal republican representative government and each province enacts its own constitution in line with the National Constitution(Government of Argentina, 1853). The legislative branch consists of two houses, and the president, vice president and cabinet of the ministers use the executive power. It has 24 administrative subdivisions that consist of 23 provinces and the autonomous city of Buenos Aires(United Nations, 2004). Argentina is the fourth most populated country in Latin America and the Caribbean region, and in 2017 it was the third largest economy in the region after Brazil and Mexico with 643 billion US \$ of GDP(IMF, 2019). On the other hand, Argentina had experienced many economic crises that caused debt defaults and as a result the country adopted 21 IMF programs since 1956(Congressional Research Service, 2018). Therefore, Argentina has an importance in the history of economic crisis and it was also one of the many developing countries affected by the global crisis.

\subsection{Pre-crisis Period in Argentina}

Argentina had a hyperinflation problem in 1989 and introduced the Convertibility Plan in 1991, which included a currency board and structural reforms to stabilize its economy. As a result, Argentina experienced a $6 \%$ average growth rate between the years 1991 and 1997 even if it had a negative growth in 1995(IMF, 2003-a).However, in 1998, the country experienced an economic slowdown with a 3.9\% GDP growth rate. In 1999 and 2000, the growth rates were negative and in 2001 Argentina had one of the worst economic crises in its history that caused another debt default. As a result, the average growth was $-4.9 \%$ between the years 1999 and 2002(IMF, 2003-b).

Table 5: Main Economic Indicators of Argentina (1990-2005)

\begin{tabular}{lrrrr}
\hline & $\mathbf{1 9 9 0}$ & $\mathbf{1 9 9 5}$ & $\mathbf{2 0 0 0}$ & $\mathbf{2 0 0 5}$ \\
\hline \hline Gross domestic product, constant prices (\%) & $-1,3$ & $-2,8$ & $-0,8$ & 8,9 \\
Inflation, average consumer prices (\%) & $\mathrm{n} / \mathrm{a}$ & $\mathrm{n} / \mathrm{a}$ & $-0,9$ & 9,6 \\
Volume of imports of goods and services (\%) & $-0,7$ & $-11,5$ & $-2,4$ & 18,4 \\
Volume of exports of goods and services (\%) & 16,8 & 25,6 & 1,9 & 11,6 \\
Current account balance (\% of GDP) & 3,0 & $-1,8$ & $-3,0$ & 2,5 \\
General government revenue (\% of GDP) & $\mathrm{n} / \mathrm{a}$ & 21,4 & 22,7 & 27,6 \\
General government total expenditure (\% of GDP) & $\mathrm{n} / \mathrm{a}$ & 23,5 & 26,0 & 24,4 \\
General government net lending/borrowing (\% of GDP) & n/a & $-2,1$ & $-3,3$ & 3,2 \\
General government gross debt (\% of GDP) & n/a & 31,7 & 42,1 & 80,3 \\
\hline
\end{tabular}

Source: Derived from IMF's World Economic Outlook Data (IMF, World Economic Outlook Data, 2019)

As is seen from Table 5, Argentina experienced negative growth in every fifth year except in 2005 that corresponds to the recovery period after the crisis in 2001.On the other hand, after experiencing hyperinflation in 1989, - as a reflection of economic downturn - Argentina had a negative inflation in 2000 and reduced its inflation to 9.6\% in 2005. Considering the international trade, Argentina had a volatile trend in terms of the growth in volume of import and export of goods and services between the years 1990 and 2005. The current account balance was also negative between the years 1991 and 2001 but after the crisis in 2001, the country had experienced a $4.5 \%$ average current account surplus between 2002 and 2005. Indeed, in the aftermath of the 2001 crisis, Argentina used the opportunity arising from favorable external conditions to raise its exports that led to current account surplus. Additionally, macroeconomic policies were directed to be more independent from the external conditions that helped the country to resist to the global economic crisis(Özdemir, 2014).

In terms of public finance, Argentina achieved a general government surplus in 2005 with increased government revenue and reduced government expenditures. But, the most remarkable development was in the gross debt as a share of GDP that increased from $31.7 \%$ in 1995 to $80.3 \%$ in 2005.

\subsection{The Impact of the Great Recession on the Argentine Economy}

As is mentioned before, the global crisis of 2008 had an enormous negative impact on world's economy as a whole but it was not as destructive as for developing countries specifically for the Latin American countries. 
Even if the GDP growth was negative in Latin American countries in 2009, economic recovery was rapid compared to the developed world(Santarcángelo \& Perrone, 2016).

Argentina recovered after the crisis of 2001 that was supported by high commodity prices, liquidity abundance and increased consumption, and this recovery led to decrease in income inequality and poverty. On the other hand, GDP growth had not been sustainable since important steps were not taken to eliminate main problems that cause" fiscal deficits, high inflation, low productivity, declining competitiveness, low quality of education and weak institutions"(OECD, 2017). In addition, policy interventions such as capital and currency controls were introduced in this period and intensified after 2007, which led to unproductiveness in the use of resources and affected growth negatively(OECD, 2017).

Table 6: Main Economic Indicators of Argentina (2006-2017)

\begin{tabular}{|c|c|c|c|c|c|c|c|c|c|c|c|c|}
\hline & 2006 & 2007 & 2008 & 2009 & 2010 & 2011 & 2012 & 2013 & 2014 & 2015 & 2016 & 2017 \\
\hline $\begin{array}{l}\text { Gross domestic product, } \\
\text { constant prices }(\%)\end{array}$ & 8,0 & 9,0 & 4,1 & $-5,9$ & 10,1 & 6,0 & $-1,0$ & 2,4 & $-2,5$ & 2,7 & $-2,1$ & 2,7 \\
\hline $\begin{array}{l}\text { Inflation, average consumer } \\
\text { prices }(\%)\end{array}$ & 10,9 & 8,8 & 8,6 & 6,3 & 10,5 & 9,8 & 10,0 & 10,6 & $\mathrm{n} / \mathrm{a}$ & $\mathrm{n} / \mathrm{a}$ & $\mathrm{n} / \mathrm{a}$ & 25,7 \\
\hline $\begin{array}{l}\text { Volume of imports of goods } \\
\text { and services (\%) }\end{array}$ & 13,0 & 22,2 & 14,6 & $-23,9$ & 39,4 & 21,6 & $-6,0$ & 3,5 & $-10,8$ & 2,6 & 3,6 & 14,2 \\
\hline $\begin{array}{l}\text { Volume of exports of goods } \\
\text { and services }(\%)\end{array}$ & 4,6 & 6,0 & $-1,0$ & $-10,8$ & 13,7 & 2,3 & $-5,8$ & $-3,7$ & $-7,8$ & $-1,6$ & 6,8 & $-0,2$ \\
\hline $\begin{array}{l}\text { Current account balance (\% of } \\
\text { GDP) }\end{array}$ & 2,8 & 2,1 & 1,5 & 2,2 & $-0,4$ & $-1,0$ & $-0,4$ & $-2,1$ & $-1,6$ & $-2,7$ & $-2,7$ & $-4,9$ \\
\hline $\begin{array}{l}\text { General government revenue } \\
\text { (\% of GDP) }\end{array}$ & 28,0 & 29,4 & 31,0 & 31,9 & 31,9 & 32,2 & 33,8 & 34,3 & 34,6 & 35,4 & 34,9 & 34,5 \\
\hline $\begin{array}{l}\text { General government total } \\
\text { expenditure ( } \% \text { of GDP) }\end{array}$ & 26,6 & 29,5 & 30,8 & 34,5 & 33,4 & 34,9 & 36,8 & 37,6 & 38,9 & 41,4 & 41,5 & 41,2 \\
\hline $\begin{array}{l}\text { General government net } \\
\text { lending/borrowing ( } \% \text { of GDP) }\end{array}$ & 1,3 & $-0,1$ & 0,2 & $-2,6$ & $-1,4$ & $-2,7$ & $-3,0$ & $-3,3$ & $-4,3$ & $-6,0$ & $-6,6$ & $-6,7$ \\
\hline $\begin{array}{l}\text { General government gross debt } \\
\text { (\% of GDP) }\end{array}$ & 70,8 & 62,1 & 53,8 & 55,4 & 43,5 & 38,9 & 40,4 & 43,5 & 44,7 & 52,6 & 53,1 & 57,1 \\
\hline
\end{tabular}

Source: Derived from IMF's World Economic Outlook Data (IMF, World Economic Outlook Data, 2019)

Table 6 demonstrates the main economic indicators of Argentina between 2006 and 2017. As is seen, after experiencing 8\% average GDP growth between 2003 and 2008, Argentina's economy downsized in 2009 with a-5.9\% GDP growth. However, as is mentioned, economic recovery was rapid after the global crisis and the GDP growth rates were 10.1\% and 6\% in 2010 and 2011.Yet, even if Argentina experienced a stabilized period in terms of GDP growth in the aftermath of the economic crisis of 2001, GDP growth had been volatile againin the years following the global crisis. In terms of the inflation rates, Argentina had a better performance between 2007 and 2009 but it increased to a 10.2\% average between 2010 and 2013, and reached to 25.7\% in 2017.

Figure 6: Average Annual Growth in Main Sectors - Argentina (Value Added, Annual \%)

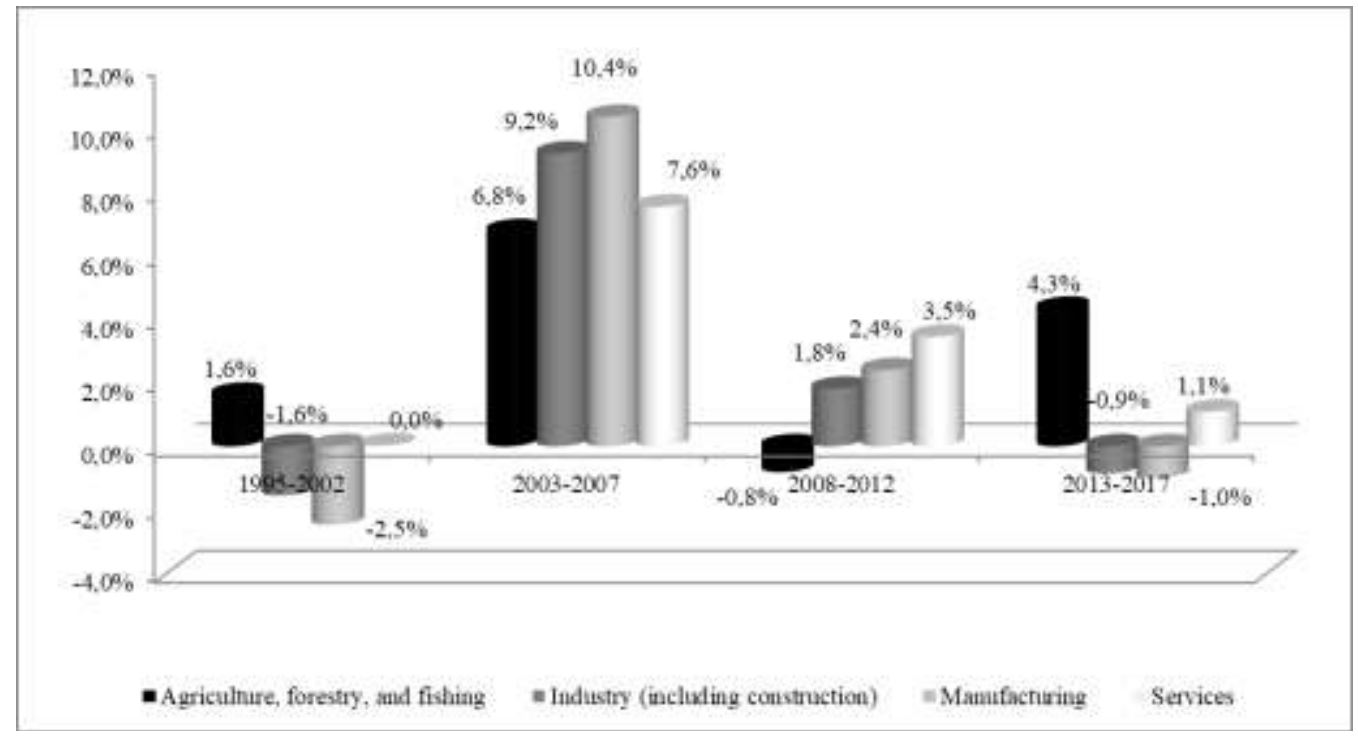

Source: Derived from the World Bank's World Development Indicators Data(The World Bank, 2019) 
Considering the sectoral developments in the Argentine economy, it can be seen from Figure 5 that industry and manufacturing sectors showed the best performance between 2003 and 2007 in comparison with the first period that covers the years 1995-2002. In addition to this, Argentina is one of the major largest exporters of soybean, diesel from soybean oil and corn, and the increase in the growth of agriculture sector was based on the strong growth in soybean and corn prices in the international market(Santarcángelo \& Perrone, 2016).However, in the following years of the global crisis, the average growth rates of each sector had decreased again, even if they were not as bad as in the first period.

The growth in volume of import and export of goods and services had been volatile from 1990 to 2017, even if the export was more stable than import. After the crisis of 2001, the growth in volume of import decreased tremendously $53.6 \%$ in 2002 - and even if it was not as sharp as the import, the growth in volume of export decreased as well. However, the average annual growth in volume of import increased staggeringly and reached $30.7 \%$ between 2003 and 2007. The increase in the average annual growth in volume of export was too slight in comparison with import which was only $5.4 \%$ in the same period. During the great recession, the annual growth in both volume of import and export declined and the average growth in import was 5.9\% between 2008 and 2017 while the average growth in volume of export was $-0.8 \%$ in the same period. Therefore, it can be interpreted that Argentina was affected by the global crisis mostly through the decrease in volume of import and export of goods and services. Indeed, Argentina's main trade partner is Brazil, and it can be said that Argentina's export can be influenced directly by Brazil since the growth of Brazil is too low(Cooney, Justo, \& Santarcángelo, 2016). As a result, Argentina experienced -2\% average current account deficit as a share of GDP between 2010 and 2017 following a 3.3\% average current account surplus as a share of GDP between 2002 and 2009.

When the public finance indicators of Argentina are examined, it is clear that general government revenue as a share of GDP continued to increase from 2006 to 2015 and decreased slightly in 2016 and 2017. On the other hand, the increase in the general government expenditure as a share of GDP was sharper than the increase in revenue, especially in 2009. It can be interpreted that Argentina implemented an expansionary expenditure policy as a respond to the global crisis. Therefore, general government deficit as a share of GDP increased as a consequence of this policy. Notwithstanding, the general government gross debt as a share of GDP decreased between 2006 and 2011 and reached its lowest level in $2011(38.9 \%)$. But beginning from the year 2012, it started to increase again and reached $57.1 \%$ in 2017 . Additionally, Figure 4 shows that Argentina had a V-shape recovery during the global crisis and when the GDP growth increased, the general government deficit decreased and vice versa. However, beginning from the year 2012, GDP growth had been volatile and general government deficit continued to increase.

\section{Figure 7: GDP Growth and General Government Deficit (Argentina)}

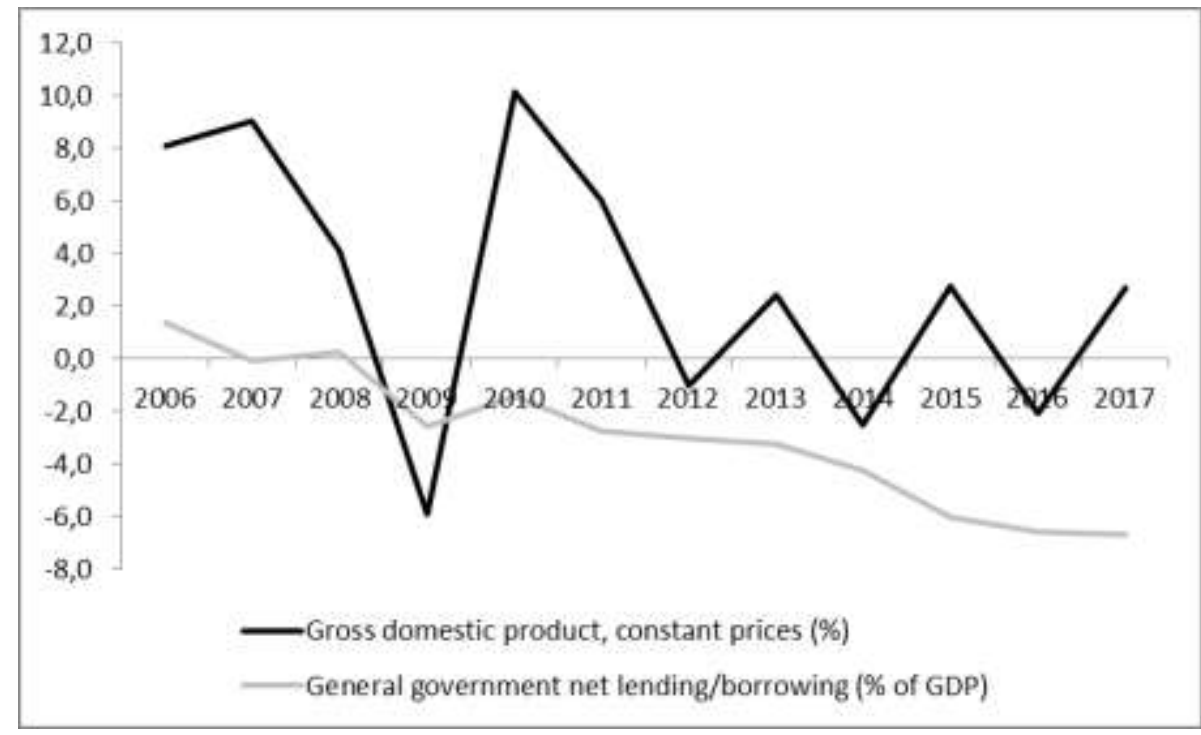

Source: Derived from IMF's World Economic Outlook Data (IMF, World Economic Outlook Data, 2019)

On the other hand, as is seen from Table 7, the foreign investments in the balance of payments of Argentina show that the country had been influenced negatively in terms of portfolio investments in both 2008 and 2009. Foreign direct investments also decreased in 2009 compared to 2008. 
Table 7: Foreign Investments of Argentina (2005-2009)

\begin{tabular}{lccccc}
\hline Millions US Dollars) & $\mathbf{2 0 0 5}$ & $\mathbf{2 0 0 6}$ & $\mathbf{2 0 0 7}$ & $\mathbf{2 0 0 8}$ & $\mathbf{2 0 0 9}$ \\
\hline \hline Foreign Direct Investments & 3.954 & 3.099 & 4.969 & 8.335 & 3.306 \\
Portfolio Investments & -387 & 7.239 & 7.468 & -7.879 & -2.153
\end{tabular}

Source: Derived from National Institute of Statistics and Censuses of the Argentine Republic (INDEC)(INDEC, 2019). In addition to this, Figure 8 below shows the foreign investments as a share of GDP for the years 1995-2017. As is seen from the figure, Argentina had been affected through the portfolio investments in both 2008 and 2009. On the other hand, the impact of the global crisis on foreign direct investments was seen in 2009, one year later than the portfolio investments. It is obvious that Argentina was affected harshly by the global crisis, yet the downturn was not as harsh as it was in 2001. In the aftermath of the global crisis, foreign investments had been volatile including both portfolio and direct investments but there were not sharp deeps or booms as in the case of 2001 and 2008 crises.

Figure 8: Foreign Investments of Argentina (\% of GDP)

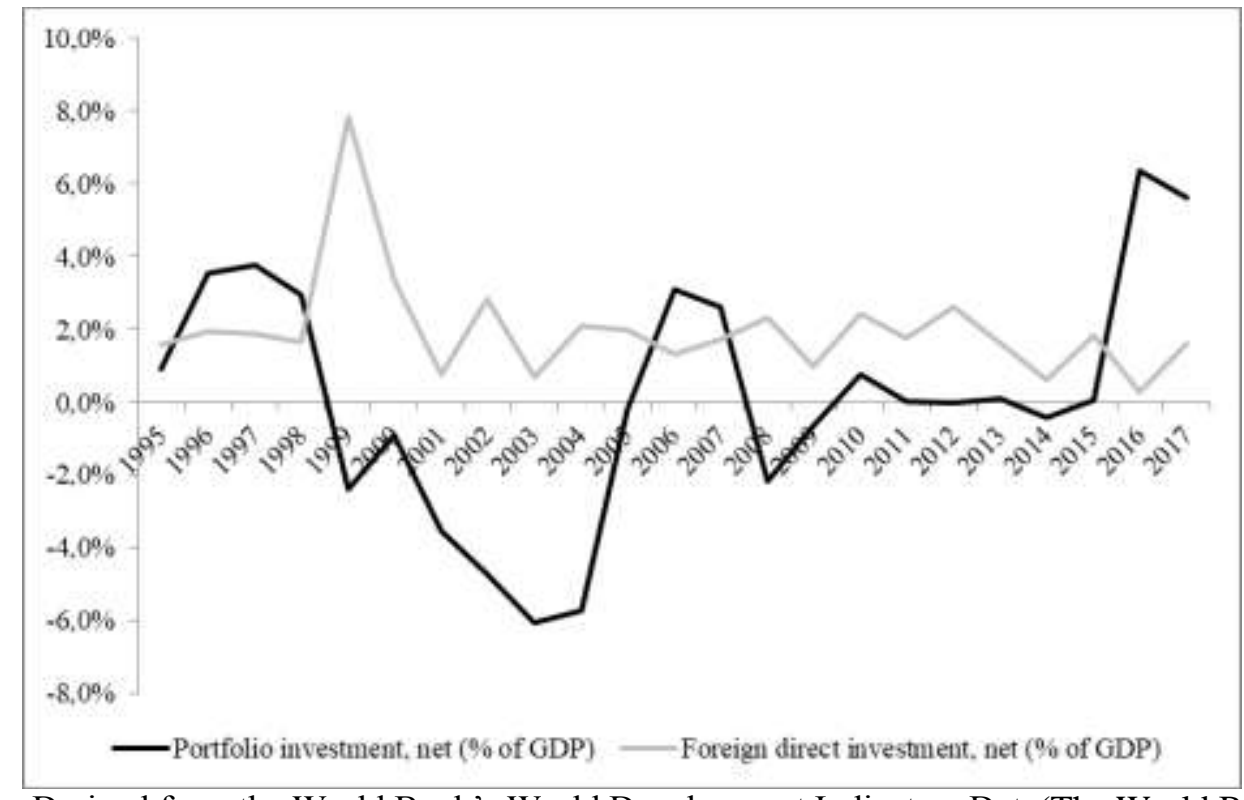

Source: Derived from the World Bank’s World Development Indicators Data(The World Bank, 2019)

\subsection{Policy Responses of Argentina to the Great Recession}

Argentina had adopted a comprehensive policy package to mitigate the adverse impacts of the global crisis of 2008 that included both monetary and fiscal interventions as well as labor market and social protection measures(International Labor Office, 2010). Additionally, because of the economic distress created by the global crisis, Argentina had used temporary trade barriers more intensely - as it did generally during the slowdown periods - between 2008 and 2010(Moore, 2011).

As is mentioned before, Argentina implemented expansionary fiscal policies during the global crisis. Main fiscal policy measures included both the revenue and expenditure sides that can be listed as renationalization of the pension system, public work program, tax reliefs for specific industries and some other important interventions to cope with unemployment and to protect vulnerable people(International Labor Office, 2010).The nationalization of the pension system was one of the most important of those measures, since Argentine government tried it before during the 2001 crisis but failed. When the great recession spread to the country, government turned the crisis to an opportunity to renationalize the pension system and private funds' assets were transferred to the national social security system(Orenstein, 2011). 
Also, some of the other measures taken by the Argentine government were; reducing the tax and social security burden on businesses, starting a cash transfer program for unemployed, initiating a youth employment and skills training program and the expansion of child benefits for the vulnerable families(International Labor Office, 2010).

On the monetary policy side, the Central Bank of Argentina took measures to provide liquidity and refrain from exchange rate volatility. As a consequence of the liquidity buffers created through fiscal and current account surpluses and the sound monetary and financial policies implemented by the Central Bank of Argentina in the pre-crisis period, Argentina was more resilient to the global crisis. Therefore, the Central Bank of Argentina was more flexible to take the required steps to mitigate the negative impacts of the global crisis when the crisis arrived the country. It operated in the foreign exchange markets to reduce the volatility of local currency and injected liquidity to the market to mitigate the adverse effect of foreign currency sales(Central Bank of Argentina, 2010).

\section{Conclusion}

The crisis of 2008 that started in the US sub-prime mortgage market was more destructive for the world economy than it was thought at the beginning. At the very early stage of the crisis, the US financial system was destroyed rapidly and financial giants collapsed such as Lehman Brothers. The crisis had spread to the other advanced economies since they had invested in the same risky innovative instruments and the global economy was highly integrated. However, even if the crisis started in the financial markets, it widened to the real sector and led to the great recession.

Developing economies had also suffered from the crisis since they were integrated to the global system, as well and mostly dependent on the export incomes and capital inflows. Therefore, the main channels that facilitated the spread of the crisis to the developing world were international trade and capital flows. India and Argentina were two of these economies that were affected negatively by the crisis even if they were located in different regions and had different conditions.

India and Argentina had severe economic crisis in 1990s and Argentina also had its most destructive crisis in 2001. As a result of those crises, they implemented structural reform programs and took policy measures such as regulatory arrangements in financial system in India and sound monetary and financial policies in Argentina. In the aftermath of the global crisis, these two countries adopted similar policy packages that mainly included expansionary fiscal and monetary measures. On the monetary side, they were both able to use monetary policy means to provide adequate liquidity to the markets within the context of narrowed financial activities in the global system. In terms of the tax policies, both of these countries used tax reliefs to support specific sectors that are mainly involved in exportation. They also focused on the additional public expenditures that mitigate the adverse effects of the crisis on employment and vulnerable people. As a consequence, even if its growth rate decreased tremendously, India had not experienced an economic downsize during the global crisis while Argentina recovered rapidly from the crisis, even if it had a negative growth rate in 2009.

\section{References}

Bajpai, N. (2002, April). A Decade of Economic Reforms in India: the Unfinished Agenda. Retrieved 04 14, 2019, from Harvard Kennedy School: https://www.hks.harvard.edu/sites/default/files/centers/cid/files/publications/faculty-working-papers/89.pdf

Bajpai, N. (2011, July). Global Financial Crisis, its Impact on India and the Policy Response. Retrieved 04 20, 2019, from Colombia Global: https://beta.global.columbia.edu/files/globalcommons2/Global\%20Financial\%20Crisis\%2C\%20its\%20Impact\%20o n\%20India\%20and\%20the\%20Policy\%20Response\%20Working\%20Paper\%205.pdf

Central Bank of Argentina. (2010). The International Banking Crisis and Its Impact on Argentina. BIS Papers: The Global Crisis and Financial Intermediation in Emerging Market Economies (pp. 97-111). Basel: Bank for International Settlements. Retrieved from Bank for International Settlements.

Congressional Research Service. (2018, October 2). Argentina's Economic Crisis. Retrieved 04 25, 2019, from Congressional Research Service: https://crsreports.congress.gov/product/pdf/IF/IF10991

Cooney, P., Justo, O., \& Santarcángelo, J. E. (2016). The Aftermath of the Global Crisis in Latin America: General Remarks and Future Perspectives. In J. E. Santarcángelo, O. Justo, \& P. Cooney (Eds.), Latin America After the Financial Crisis: Economic Ramifications From Hederodox Perspectives (pp. 229-248). New York: Palgrave Macmillan.

Government of Argentina. (1853). Constitution of the Argentine Nation. Retrieved 04 25, 2019, from Ministerio de Justicia y Derechos Humanos - Biblioteca Sede Central: http://www.biblioteca.jus.gov.ar/argentina-constitution.pdf

Government of India. (2015, 11 9). The Constitution of the India. Retrieved 04 14, 2019, from Ministry of Law and Justice Legislative Department: http://legislative.gov.in/sites/default/files/coi-4March2016.pdf 
IMF. (2003-a, July). The Role of Tthe IMF in Argentina, 1991-2002. Retrieved 04 25, 2019, from International Monetary Fund: https://www.imf.org/External/NP/ieo/2003/arg/070403.pdf

IMF. (2003-b, October 8). Lessons from the Crisis in Argentina. Retrieved 04 25, 2019, from International Monetary Fund: https://www.imf.org/external/np/pdr/lessons/100803.pdf

IMF. (2009, January 28). World Economic Outlook Update: Global Economic Slump Challenges Policies. Retrieved 04 05, 2019, from International Monertary Fund: https://www.elibrary.imf.org/abstract/IMF081/093379781589067585/09337-9781589067585/binaries/ENG_JAN_UPDATE_2009.pdf?redirect=true

IMF. (2019, April). World Economic Outlook Data. Retrieved 04 25, 2019, from International Monetary Fund: https://www.imf.org/external/pubs/ft/weo/2019/01/weodata/weoselagr.aspx

INDEC. (2019). Balanza de pagos. Retrieved 04 28, 2019, from Instituto Nacional de Estadística y Censos de la República Argentina:

https://www.indec.gob.ar/nivel4_default.asp?id_tema_1=3\&id_tema_2=35\&id_tema_3=45

International Labor Office. (2010, April 20-21). G 20 Country Briefs: Argentina's Response to the Crisis. Retrieved 04 29, 2019, from U.S. Department of Labor: https://www.dol.gov/ilab/diplomacy/G20_ministersmeeting/G20-Argentinabrief.pdf

Jansen, M., \& Von Uexkull, E. (2010). Trade and Employment in the Global Crisis. Geneva: International Labour Office.

Keeley, B., \& Love, P. (2010). From Crisis to Recovery: The Causes, Course and Consequences of the Great Recession. OECD Publications.

Khan, M. S. (2011). Fiscal Policy Response in India to Global Financial Crises. Indian Journal of Politics, 45.

Lin, J. Y. (2008, 31 10). The Impact of the Financial Crisis on Developing Countries. Retrieved 04 02, 2019, from The World Bank: http://siteresources.worldbank.org/ROMANIAEXTN/Resources/Oct_31_JustinLin_KDI_remarks.pdf

Mohanty, D. (2009, 11 12). Global Financial Crisis and Monetary Policy Response in India. In C. f. Entwicklung (Ed.), 3rd Indian Council for Research on International Economic Relations-Internationale Weiterbildung und Entwicklung (ICRIER-InWEnt) Annual Conference. New Delhi: Bank for International Settlement. Retrieved 04 22, 2019, from Bank for International Settlement: https://www.bis.org/review/r091217f.pdf

Moore, M. O. (2011). Argentina: There and Back Again? In C. P. Bown (Ed.), The Great Recession and Import Protection: The Role of Temporary Trade Barriers (pp. 317-350). Washington, DC: Office of the Publisher, The World Bank.

Naudé, W. (2009, 01). The Financial Crisis of 2008 and the Developing Countries . Retrieved 04 02, 2019, from United Nations University: https://www.wider.unu.edu/sites/default/files/dp2009-01.pdf

Nayyar, D. (2011, January). The Financial Crisis, the Great Recession and the Developing World. Global Policy, 2(1), 2032.

OECD. (2017). OECD Economic Surveys: Argentina 2017 Multi-Dimensional Economic Survey. Paris: OECD Publishing.

Orenstein, M. A. (2011, July 03). Pension privatization in crisis: Death or rebirth of a global policy trend? International Social Security Review, 64(3), 65-80.

Özdemir, Y. (2014, July 19-24). Argentina, Brazil, and Mexico in the Face of the Global Economic Crisis: What Economic Strategies Work Best? Retrieved 04 29, 2019, from Semantic Scholar: https://pdfs.semanticscholar.org/9057/a753939e724bf362ca47a3b375fb25914f75.pdf

Priewe, J. (2010). What Went Wrong? Alternative Interpretation of the Global Financial Crisis. In S. Dullien, D. J. Kotte, A. Márquez, \& J. Priewe (Eds.), The Financial and Economic Crisis of 2008-2009 and Developing Countries (pp. 1752). New York \& Geneva: United Nations Publication.

Reddy, Y. V. (2010). Regulation of the Financial Sector in Developing Countries: Lessons from the 2008 Financial Crisis. In S. Griffith-Jones, J. A. Ocampo, \& J. E. Stiglitz (Eds.), Time for a Visible Hand: Lessons from the 2008 World Financial Crisis (pp. 242-252). New York: Oxford University Press.

Reserve Bank of India. (2011, December 12). RBI Bulletin. Retrieved 04 22, 2019, from Reserve Bank of India: https://www.rbi.org.in/scripts/BS_ViewBulletin.aspx?Id=3902

Roubini, N., \& Mihm, S. (2010). Crisis Economics: A Crash Course in The Future of Finance. New York: The Penguin Press.

Santarcángelo, J. E., \& Perrone, G. (2016). The Global Crisis and Its Effects on the Accumulation in Argentina. In J. E. Santarc á ngelo, O. Justo, \& P. Cooney (Eds.), Latin America After the Financial Crisis: Economic Ramifications From Hederodox Perspectives (pp. 33-58). New York: Palgrave Macmillan.

Steger, M. B., \& Roy, R. K. (2010). Neoliberalism: A Very Short Introduction. New York: Oxford University Press.

The World Bank. (2010). Post-Crisis Growth in Developing Countries. Washington, DC: The World Bank.

The World Bank. (2019). Data Bank World Development Indicators. Retrieved 04 20, 2019, from The World Bank: https://databank.worldbank.org/data/source/world-development-indicators\#

United Nations. (2004, January). Republic of Argentina: Public Administration Country Profile. Retrieved 04 25, 2019, from United Nations: http://unpan1.un.org/intradoc/groups/public/documents/un/unpan023191.pdf 